\title{
Temporary restorative materials used by Brazilian Dental Schools during and after endodontic treatment
}

\author{
Materiais restauradores temporários usados pelas faculdades de \\ Odontologia brasileiras durante e após tratamento endodôntico
}

\author{
Natasha Capitani Symanski* \\ Paola Juber* \\ Renata Dornelles Morgental** \\ Roberta Kochenborger Scarparo ${ }^{* * *}$ \\ Fabiana Vieira Vier-Pelisser ${ }^{* * *}$
}

\begin{abstract}
Objective: this study aimed at evaluating which temporary restorative materials are recommended by Brazilian Dental Schools (BDS), during and after endodontic treatment completion. Methods: a questionnaire was distributed to all 191 BDS, and returned by 55 (28.8\%) schools. Topics of interest included: which temporary restorative materials are advised in different remaining dental conditions and different permanence periods in the mouth, minimum material thickness, intermediate material application, use of matrix band and factors influencing material selection. Results: the answers showed that the remaining coronal tooth structure significantly interferes with the choice of temporary restorative materials. On the other hand, time between appointments does not have significant influence on material selection. Still, premixed hygroscopic materials are recommended in cases of simple endodontic access (occlusal or lingual/palatal) if the material will be kept for up to one week in the month. Glass ionomer cement (GIC) is the most commonly used material in long periods, especially for access cavities involving proximal surfaces or fractured cusps. The utilization of an intermediate material is very variable and some schools do not advocate any material. Most BDS recommend a minimum thickness of $3 \mathrm{~mm}$ for temporary restorations and the use of matrix band in proximal surfaces. Conclusion: BDS choices with respect to coronal sealing materials are driven especially by remaining dental conditions.
\end{abstract}

Keywords: Dental materials. Endodontics. Temporary dental restoration.

\section{Introduction}

Bacterial infection is the most common cause of pulpal and periradicular disease ${ }^{1}$. Also, preventing the entrance of bacteria in all phases of endodontic therapy is a basic principle for its success. In many situations, the treatment is not concluded in a single session and requires a temporary restoration in order to avoid the penetration of fluids, organic materials and microbes from the oral cavity into the root canal system. However, in vitro and in vivo studies have shown that no temporary restorative material is able to totally prevent infiltration into the tooth/material interface ${ }^{2-10}$.

Moreover, definitive restorative materials should be used after root canal filling and must provide adequate sealing and resistance to masticatory forces. An inadequate restoration represents an important cause of failure in endodontically treated teeth $^{11,12}$. The literature suggests that, in these situations, prognosis can be improved by sealing the canal and minimizing the leakage of oral fluids and bacteria into periradicular areas as soon as possible after root canal therapy conclusion ${ }^{13}$.

The remaining coronal tooth structure seems to influence the sealing ability of temporary restorations. Materials that provided proper seals in standardized access preparations, within intact tooth structures, were unacceptable in complex access

DDS, Department of Endodontics, School of Dentistry, Pontifical Catholic University of Rio Grande do Sul (PUCRS), Porto Alegre, RS, Brazil.

PhD, Post-Doctoral Student, Department of Endodontics, School of Dentistry, Pontifical Catholic University of Rio Grande do Sul (PUCRS), Porto Alegre, RS, Brazil.

PhD, Professor, Department of Endodontics, School of Dentistry, Pontifical Catholic University of Rio Grande do Sul (PUCRS), Porto Alegre, RS, Brazil. 
preparations with multi-surface and cusps involvement $^{14}$. Also, permanence time in the access cavity is an important aspect to be considered in clinical practice $^{5,8}$. It is uncertain if these factors interfere with material selection in Brazilian Dental Schools (BDS) and if their choices of coronal sealing materials are based on current scientific evidence. The importance of coronal sealing is well recognized ${ }^{15}$, so this topic must be correctly approached in university facilities.

Besides being effective in sealing, it is essential that a temporary restoration not impair the subsequent access to the root canals. Thus, an intermediate material is frequently used between the intracanal medication and the restorative material ${ }^{10}$, but it should ensure an adequate thickness of the lat$\operatorname{ter}^{16}$. Some materials are very technique-sensitive and inattention to operative steps required during clinical application may affect treatment outcome ${ }^{17}$.

This study aimed to evaluate, by using questionnaires, which temporary restorative materials are recommended by BDS during and after endodontic treatment completion, considering the amount of coronal tooth structure and the permanence time in the mouth.

\section{Methods}

This study was approved by the Research Ethics Committee of the Pontifical Catholic University of Rio Grande do Sul (PUCRS), protocol number $11 / 05684$.

A closed questionnaire containing 11 questions was developed regarding temporary restorative materials recommended by BDS in different dental conditions, considering the permanence of the material for up to a week, more than two weeks, and after endodontic treatment completion. Remaining coronal tooth structure of endodontically involved teeth was classified into three categories: simple endodontic access (Endo Ac), i. e., conventional lingual/palatal cavity for incisors and canines or occlusal cavity for premolars and molars; endodontic access associated with cavity preparation involving one or two proximal surfaces (Endo Ac + Prox); presence of fractured buccal or lingual/palatal cusps (Endo Ac + Fract).

Materials available on the response options were: premixed hygroscopic materials, glass ionomer cement (GIC), reinforced zinc oxide-eugenol (ZOE) cement, zinc phosphate cement, light cured resin-based materials, composite resin, amalgam and other. In this latter situation, the additional material should have been quoted.

The questionnaire also contained questions related to temporary restorative material minimum thickness, utilization of an intermediate material between the restoration and the intracanal medica- tion or filling material, indication for using matrix band in cases of proximal cavities and clinical factors affecting material selection.

An updated list (October/2011) of all BDS was obtained from the Brazilian Dental Association $(\mathrm{ABO} / \mathrm{RS})$ records. The questionnaire was sent to the chairman of the Department of Endodontics of each one of the 191 universities, via Brazilian Post Service, along with written informed consent and a sealed envelope for returning the completed questionnaire. BDS were also contacted by email to reaffirm the importance of the study and to enhance the return of responses.

The answers concerning temporary materials used in different dental conditions for up to a week, more than two weeks, and after endodontic treatment were compared by two-way ANOVA, followed by Bonferroni test with a significance level of $5 \%$. The frequency of the other responses were expressed as percentages.

\section{Results}

In this study, $55(28.8 \%)$ out of 191 BDS returned the questionnaire. Most of these schools are located in the South (16 schools - 29.1\%) and Southeast (27 schools - 49.1\%) regions of Brazil.

No significant difference was detected between the choices of temporary restorative materials regarding the time they would remain in the mouth or the moment of sealing, i.e., interappointment or after endodontic treatment ( $p>0.05)$.

The dental condition interfered in the temporary sealing material selection $(\mathrm{p}<0.05)$. Premixed hygroscopic materials and glass ionomer cement (GIC) were recommended by BDS in situations where simple endodontic access is performed and if the material would remain for up to a week. GIC was the most frequently used material for more than two weeks or after root canal filling (Figure 1). Moreover, GIC was the most indicated material in all time periods when at least one proximal surface is involved (Figure 2).

When the treated tooth has fractured buccal or lingual/palatal cusps, although GIC remained the material of choice, regardless of the time period, we found a great number of schools indicating composite resins as temporary endodontic material (Figure 3).

Regarding the five factors cited by BDS, which should be considered when selecting the temporary material, there were: cavity extension $(85.18 \%)$, permanence time in the mouth $(77.77 \%)$, amount of forces received during chewing $(72.22 \%)$, aesthetics $(37.03 \%)$ and material setting time (12.96\%). Considering the most important factor among those discussed, we had: extension of the cavity (42.59\%), permanence time $(31.48 \%)$ and amount of masticatory forces $(22.22 \%)$. 
In regard to temporary restorative material minimum thickness, most BDS $(74.54 \%)$ chose $3 \mathrm{~mm}$.

The majority of BDS (58.18\%) responded they use a cotton pellet between the intracanal medication and the restorative material, while $9.09 \%$ use no intermediate material. Between the restorative material and the root canal filling, $29.09 \%$ use a premixed hygroscopic material, while $32.72 \%$ reported they do not use any intermediate material. Other materials were mentioned, such as: cotton pellet (14.54\%), gutta-percha sticks (14.54\%) and GIC $(5.45 \%)$.

During temporary material insertion into cavities with proximal involvement, $81.81 \%$ of the respondents recommended the use of a matrix band.

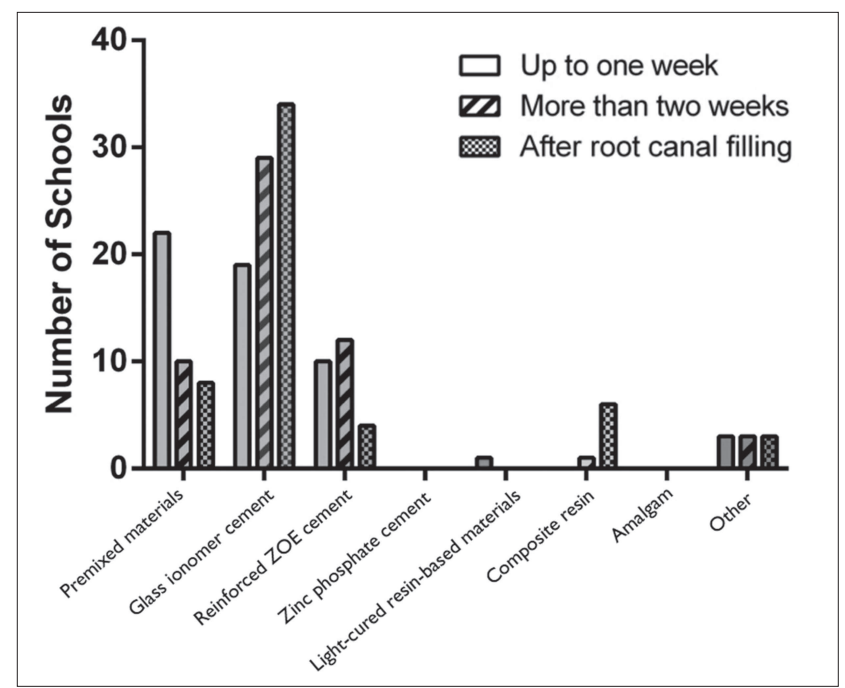

Figure 1 - Temporary restorative materials recommended by BDS in cases of conventional endodontic access, according to permanence time in the mouth

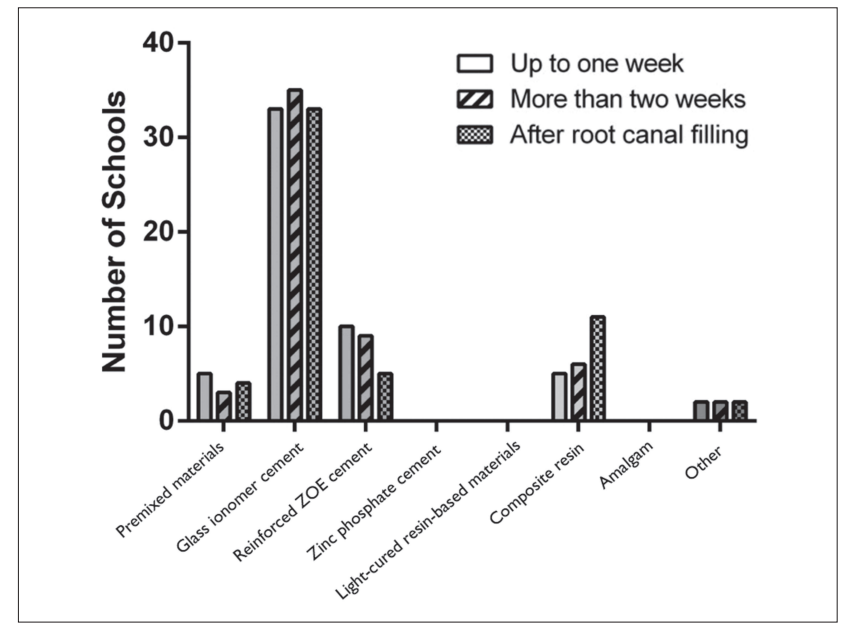

Figure 2 - Temporary restorative materials recommended by BDS in cases of endodontic access and cavity preparation involving one or two proximal surfaces, according to perma-

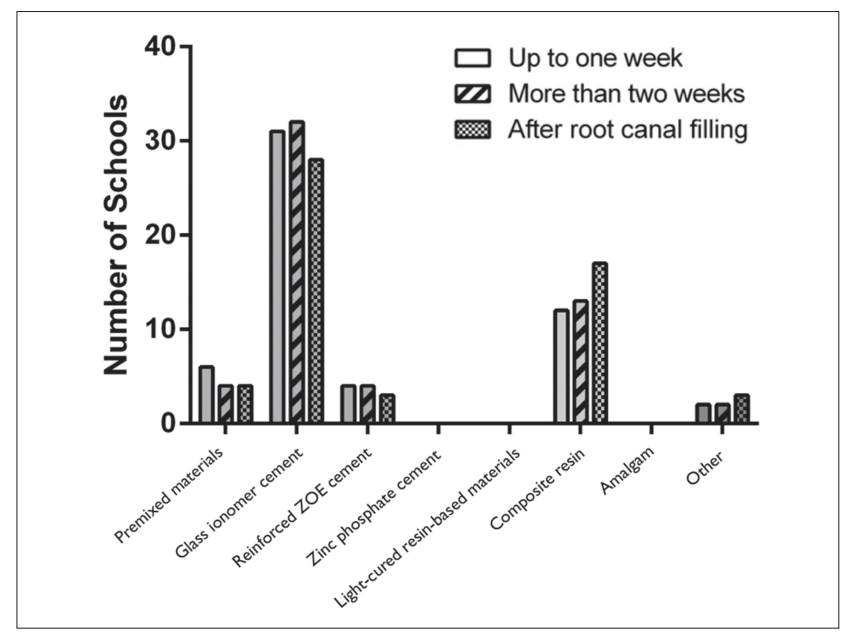

Figure 3 - Temporary restorative materials recommended by BDS in cases of endodontic access and presence of fractured buccal or lingual/palatal cusps, according to permanence time in the mouth

\section{Discussion}

The university is an environment prone to generate knowledge and opinions. Grounded in academic experiences, new professionals usually apply in their routine clinical life the habits acquired during their training in Dental School. In this context, it is relevant to investigate dental materials used in different clinical situations by BDS, in order to verify the cohesion among different schools, and also for a reflection about the consistency between theoretical knowledge and what is used in clinical practice.

Then, the present study approached the influence of different factors on BDS academic recommendations of temporary sealing materials. Our results demonstrate that the remaining coronal condition significantly influenced material selection. Moreover, $42.59 \%$ of BDS selected "cavity extension" as the most important factor that should be considered in the decision making process. According to Naoum and Chandler ${ }^{10}$ (2002), materials with proper marginal sealing capacity are not sufficient in teeth with great dental structure loss. These situations require a material with good physical properties allowing satisfactory rubber dam placement.

No significant differences were found in the choice of temporary restorative materials with respect to the permanence time in the mouth or the moment of sealing, i.e., interappointment (up to a week and more than two weeks) or after endodontic treatment. We may say there were contrasts between theoretical knowledge about the most effective material and what is clinically performed. Some BDS still recommend materials with poor physical properties for long periods. However, when asked about the factors that interfere in temporary restorative material selection, $77.77 \%$ of BDS stated that permanence time is one of the most important aspects. 
According to the answers, premixed hygroscopic materials should be recommended for simple access cavities and short periods. These products usually contain zinc oxide, calcium sulphate, resins and pigments ${ }^{10}$. These results corroborate findings of Deveaux et al. ${ }^{5}$ (1999) who showed that Cavit (3M ESPE, St. Paul, MN, USA) is a clinically effective and popular temporary restorative material, which keeps good marginal seal up to 21 days in cases of endodontic access without proximal involvement or crown destruction. The satisfactory sealing ability of Cavit and other ready-to-use materials can be explained by their hygroscopic nature and the linear expansion after setting ${ }^{18}$.

Low compressive strength and deterioration over time are the major drawbacks of this group of materials ${ }^{10}$. Some BDS (5.45\%) cited the use of double seal composed by a premixed hygroscopic material covered with reinforced ZOE cement. According to Pai et al. ${ }^{19}$ (1999), who used an inner layer of Caviton (GC Corporation, Tokyo, Japan) and an outer layer of IRM (Dentsply International, Milford, DE, USA), this approach could compensate for inadequate physical properties of the first material and it showed better dentin adaptation than IRM alone.

GIC is the main temporary restorative material recommended by BDS for intervals greater than two weeks and after root canal filling. Its use as a temporary material during endodontic therapy has been investigated in several studies with favorable results ${ }^{17,20-22}$. Moreover, GIC possess antibacterial properties against several bacterial strains ${ }^{23-25}$. In a previous investigation ${ }^{8}$, although GIC did not provide optimal sealing capacity after two weeks, it was similar to a premixed hygroscopic material (Coltosol - Coltene, Cuyahoga Falls, OH, USA) and superior to IRM.

Regarding the proper material to be used after completion of endodontic treatment when at least one proximal surface is involved, $60 \%$ and $20 \%$ of BDS use GIC and composite resin as coronal sealing material, respectively. In particular, it should be noted that the questionnaire considered the fact that the patient would be referred to the final restoration, shortly after endodontic obturation. Even so, there were a significant number of respondents that employ composite resin, showing concern with cavity hermetic sealing immediately after root canal filling. By comparing these two materials, it has been shown that GIC possess inferior aesthetic appearance and lower compressive strength than composites ${ }^{10}$. Also, microleakage studies have shown better results with composite resin ${ }^{4,26,27}$.

These results suggest that it may be more prudent to use a permanent material for provisional restorations to prevent inadequate canal sealing and the resulting risk of fluid penetration, especially in complex cavities. Due to time, cost or factors inherent to university organization, resin composite restorations may not be possible immediately after endodontic treatment and then GIC is frequently advocated in BDS facilities.

As shown in Figure 2, a small percentage of BDS employs premixed hygroscopic materials in situations with proximal surface involvement. However, in complex endodontic access cavities, the use of such materials (e.g., Cavit, Coltosol) has been disputed. The linear setting expansion of Cavit proved to be disadvantageous in proximal boxes due to lack of restraining influence exerted by the cavity walls ${ }^{3}$. Then, this class of materials requires sufficient dentinal walls to withstand such expansion, in order to increase their potential for cavity sealing ${ }^{6}$.

Most BDS (74.50\%) chose the minimum thickness of $3 \mathrm{~mm}$ for the temporary restorative material. It has been shown that material thickness is directly related to coronal leakage and compressive strength $^{7,28}$. Also, it seems to be influenced by certain conditions, as being involved or not by healthy dental structure and the existence of occlusal masticatory forces. In ideal conditions, a thickness of $3 \mathrm{~mm}$ provides adequate sealing and at the same time, it is easily removed, if necessary ${ }^{16}$.

The use of a cotton pellet over canal orifices is a controversial step during temporization. It is used as an intermediate material between the intracanal medicament and the temporary restoration by the majority of BDS (63.04\%). The advantage is the ease of removal of the temporary material without taking the risk of unnecessary removal of intact tooth structure or even worse, perforating the pulp-chamber floor. Placement of a cotton layer can also preclude the accidental blockage of the root canal by small fragments of the temporary restoration. However, caution must be taken because the cotton pellet may reduce the thickness of the temporary material and compromise the stability of the restoration by acting as a cushion allowing displacement during masticatory loading ${ }^{10}$.

In regard to intermediate materials used between the filling material and the coronal restoration, a relevant number of schools $(29.09 \%)$ recommends premixed hygroscopic materials. Dammam et al. ${ }^{29}$ (2012) showed that a cervical barrier of Coltosol (1 $\mathrm{mm}$ ) under GIC or composite resin improved coronal seal. Moreover, a protection plug with this type of material over endodontic obturation in teeth with post space preparation seems to impair bacteria leakage from oral cavity ${ }^{30}$.

From all questioned BDS, 80.39\% indicate the use of matrix bands in cavities with proximal involvement. The incremental deposition of the temporary material in a matrix-supported cavity results in a well-condensed restoration ${ }^{3}$. Poor packing, condensing or insertion of restorative material leads to increased dimensional changes on setting and polymerization, early dissolution of the materials, and poor marginal fit ${ }^{31}$. 
Finally, it is noteworthy that none of the commercially available products can meet all the requirements of an ideal temporary restorative material, including good sealing ability, compressive strength, aesthetics and cost. Therefore, ethical practice and clinical judgment should prevail when choosing the proper material for each situation. Also, additional studies are needed in the search for products with satisfactory properties.

\section{Conclusions}

Based on the answers of $55 \mathrm{BDS}$, the remaining tooth structure exerts significant influence on the choice of temporary restorative materials in endodontically treated cases, unlike the permanence time in the mouth. Premixed hygroscopic materials and GIC are the main choices for these schools.

\section{Resumo}

Objetivo: este estudo teve como objetivo avaliar quais materiais restauradores temporários são recomendados pelas faculdades de Odontologia brasileiras (FOB), durante e após a conclusão do tratamento endodôntico. Métodos: um questionário foi distribuído para todas as FOBs, 191 ao todo, e respondido por 55 (28,8\%) escolas. Os tópicos de interesse incluíam: quais materiais restauradores temporários são aconselhados em diferentes condições coronárias e períodos de permanência em boca, espessura mínima para esses materiais, aplicação de material intermediário, uso de matriz e fatores que influenciam a seleção do material. Resultados: as respostas mostraram que a quantidade de estrutura dental remanescente interfere significativamente na escolha dos materiais restauradores temporários. Por outro lado, o tempo entre as consultas não tem influência significativa sobre a seleção do material. Ainda assim, materiais endurecidos pela umidade são recomendados no caso de acesso endodôntico simples (oclusal ou lingual/palatino), se o material for permanecer até uma semana em boca. O cimento de ionômero de vidro (CIV) é o material mais comumente usado em longos períodos, especialmente em cavidades de acesso envolvendo superfícies proximais ou cúspides fraturadas. A utilização de um material intermediário é bastante variável, e algumas escolas não preconizam nenhum material. A maioria das FOBs recomenda uma espessura mínima de $3 \mathrm{~mm}$ para restaurações temporárias e a utilização de matriz em superfícies proximais. Conclusão: as escolhas das FOBs com respeito aos materiais de selamento coronário são impulsionadas especialmente pela condição da coroa dentária.

Palavras-chave: Endodontia. Materiais dentários. Restauração dentária temporária.

\section{References}

1. Kakehashi S, Stanley HR, Fitzgerald RJ. The effects of surgical exposures of dental pulps in germ-free and conventional laboratory rats. Oral Surg Oral Med Oral Pathol 1965; 20(3):340-9.

2. Mayer T, Eickholz P. Microleakage of temporary restorations after thermocycling and mechanical loading. J Endod 1997; 23(5):320-2.

3. Iqbal MK, Saad NA. Microleakage of cavit in varnish-lined, matrix-supported endodontic access preparations. J Endod 1998; 24(7):465-7.

4. Uranga A, Blum JY, Esber S, Parahy E, Prado C. A comparative study of four coronal obturation materials in endodontic treatment. J Endod 1999; 25(3):178-80.

5. Deveaux E, Hildelbert P, Neut C, Romond C. Bacterial microleakage of Cavit, IRM, TERM, and Fermit: a 21-day in vitro study. J Endod 1999; 25(10):653-9.

6. Uctasli MB, Tinaz AC. Microleakage of different types of temporary restorative materials used in endodontics. J Oral Sci 2000; 42(2):63-7.

7. Kampfer J, Gohring TN, Attin T, Zehnder M. Leakage of food-borne Enterococcus faecalis through temporary fillings in a simulated oral environment. Int Endod J 2007; 40(6):471-7.

8. Madarati A, Rekab MS, Watts DC, Qualtrough A. Time-dependence of coronal seal of temporary materials used in endodontics. Aust Endod J 2008; 34(3):89-93.

9. Ciftci A, Vardarli DA, Sonmez IS. Coronal microleakage of four endodontic temporary restorative materials: an in vitro study. Oral Surg Oral Med Oral Pathol Oral Radiol Endod 2009; 108(4):e67-e70.

10. Naoum HJ, Chandler NP. Temporization for endodontics. Int Endod J 2002; 35(12):964-78.

11. Saunders WP, Saunders EM. Coronal leakage as a cause of failure in root-canal therapy: a review. Endod Dent Traumatol 1994; 10(3):105-8.

12. Ricucci D, Siqueira Jr. JF. Recurrent apical periodontitis and late endodontic treatment failure related to coronal leakage: a case report. J Endod 2011; 37(8):1171-5.

13. Heling I, Gorfil C, Slutzky H, Kopolovic K, Zalkind M, Slutzky-Goldberg I. Endodontic failure caused by inadequate restorative procedures: review and treatment recommendations. J Prosthet Dent 2002; 87(6):674-8.

14. Anderson RW, Powell BJ, Pashley DH. Microleakage of temporary restorations in complex endodontic access preparations. J Endod 1989; 15(11):526-9.

15. Ray HA, Trope M. Periapical status of endodontically treated teeth in relation to the technical quality of the root filling and the coronal restoration. Int Endod J 1995; 28(1):12-8.

16. Roghanizad N, Jones JJ. Evaluation of coronal microleakage after endodontic treatment. J Endod 1996; 22(9):471-3.

17. Azevedo MS, Vilas Boas D, Demarco FF, Romano AR. Where and how are Brazilian dental students using Glass lonomer Cement? Braz Oral Res 2010; 24(4):482-7.

18. Webber RT, del Rio CE, Brady JM, Segall RO. Sealing quality of a temporary filling material. Oral Surg Oral Med Oral Pathol 1978; 46(1):123-30. 
19. Pai SF, Yang SF, Sue WL, Chueh LH, Rivera EM. Microleakage between endodontic temporary restorative materials placed at different times. J Endod 1999; 25(6):453-6.

20. Bobotis HG, Anderson RW, Pashley DH, Pantera Jr. EA. A microleakage study of temporary restorative materials used in endodontics. J Endod 1989; 15(12):569-72.

21. Lim KC. Microleakage of intermediate restorative materials. J Endod 1990; 16(3):116-8.

22. Barthel CR, Strobach A, Briedigkeit H, Gobel UB, Roulet JF. Leakage in roots coronally sealed with different temporary fillings. J Endod 1999; 25(11):731-4.

23. Tobias RS, Browne RM, Wilson CA. Antibacterial activity of dental restorative materials. Int Endod J 1985; 18(3):161-71.

24. Chong BS, Owadally ID, Pitt Ford TR, Wilson RF. Antibacterial activity of potential retrograde root filling materials. Endod Dent Traumatol 1994; 10(2):66-70.

25. Herrera M, Castillo A, Baca P, Carrion P. Antibacterial activity of glass-ionomer restorative cements exposed to cavity-producing microorganisms. Oper Dent 1999; 24(5):286-91.

26. Jensen AL, Abbott PV. Experimental model: dye penetration of extensive interim restorations used during endodontic treatment while under load in a multiple axis chewing simulator. J Endod 2007; 33(10):1243-6.

27. Abuabara A, Santos AJ, Aguiar FH, Lovadino JR. Evaluation of microleakage in human, bovine and swine enamels. Braz Oral Res 2004; 18(4):312-6.

28. Mallmann A, Ataide JC, Amoedo R, Rocha PV, Jacques LB. Compressive strength of glass ionomer cements using different specimen dimensions. Braz Oral Res 2007; 21(3):204-8.

29. Dammam D, Grazziotin-Soares R, Farina AP, Cecchin D. Coronal microleakage of restorations with or without cervical barrier in root-filled teeth. Rev Odonto Cienc 2012; 27(3):208-12.

30. Holland R, Manne LN, de Souza V, Murata SS, Dezan Junior E. Periapical tissue healing after post space preparation with or without use of a protection plug and root canal exposure to the oral environment. Study in dogs. Braz Dent $J$ 2007; 18(4):281-8.

31. Going RE. Microleakage around dental restorations: a summarizing review. J Am Dent Assoc 1972; 84(6):1349-57.

Endereço para correspondência:

Renata Dornelles Morgental

Programa Nacional de Pós-Doutorado

Faculdade de Odontologia

Pontífica Universidade Católica do

Rio Grande do Sul - PUCRS

Av. Ipiranga 6681, Prédio 6

90619-900 Porto Alegre/RS - Brasil

Fone: 555133203538

E-mail: remorgental@hotmail.com

Recebido: 09/05/2013. Aceito: 29/06/2013. 